\title{
TEOLOGI PEMBANGUNAN BERBASIS PENGEMBANGAN MASYARAKAT SHALOM PADA GEREJA KEMAH INJIL INDONESIA DAERAH KUPANG NUSA TENGGARA TIMUR
}

\author{
Yunus D. A. Laukapitangl)* \\ 1) Dosen Sekolah Tinggi Teologi Injili dan Kejuruan Kupang \\ ${ }^{*}$ Penulis korespondensi: nus_lau@yahoo.com
}

\begin{abstract}
Abstrak
Transformasi dunia dengan kuasa Kristus yang bangkit. Tahun 2011-2016 dengan Advokasi trasformasi membangun masyarakat damai melalui kuasa Kristus yang bangkit. Dalam konteks Indonesia secara umum dan masyarakat Nusa Tenggara Timur, secara khusus jemaat Gereja Kemah Injil Indonesia Daerah Kupang-NTT yang umumnya berada di pedesaan secara standard nasional belum mengalami kesejahteraan secara umum dibandingkan dengan daerah yang lain. Adapun tujuan dari penulisan ini adalah untuk menjelaskan prinsip-prinsip pembangunan masyarakat damai secara umum maupun Alkitab serta pendekatan konsep pengembangan masyarakat sehingga pada akhirnya bagaimana prinsip-prinsip teologi dan umum yang berhubungan dengan pengembangan masyarakat dapat diaplikasikan dalam berbagai program pembangunan gereja bagi jemaat sehingga dapat terjadi perubahan dalam kehidupan masyarakat menuju masyarakat shalom itu. Hasil penelitian menunjukkan bahwa pemahaman yang benar mengenai teologi pembangunan melalui pendekatan pengembangan masyarakat shalom memberi dampak secara langsung bagi kemandirian umat GKII Daerah Kupang bila bersatu hati, pikiran dan tindakan dalam membangun perencanaan strategis bersama untuk memaksilkan potensi alam, sumber daya sosial, rohani dan manusia untuk menghadirkan masyarakat shalom pada Gereja Kemah Injil Indonesia Daerah Kupang - NTT.
\end{abstract}

Kata Kunci: Teologi Pembangunan, pengembangan, masyarakat, shalom, GKII, Kupang

The transformation of the world through the power of the risen Christ. For the years 2011-2016, a transformation campaign to raise up a community of peace through the power of the risen Christ. In the Indonesian context in general and society in East Nusa Tenggara, specifically in the congregation of the Gereja Kemah Injil Indonesia in the area of Kupang-NTT, that according to national standard is in a rural area, has not yet experienced prosperity when compared to other areas. The purpose of this writing is to explain the general and biblical principles of building a community of peace, along with the approach of the concept of community development so that, in the end, the general and theological principles that are related to community development can be applied in various programs of church planting for the congregation so that it 
will produce change in the lives of the community that will move towards the aforementioned community of peace. The results of this research show that a right understanding about community development theology through the approach of developing a community of peace, has an immediate impact on the independence of the congregation of the Kupang GKII when they have one heart, mind, and act in building a strategic plan together to maximize their natural resources, as well as their social, spiritual and human resources in order to bring a community of peace to the Gereja Kemah Injil Indonesia Area Kupang-NTT.

Key words: Theology of Community Development, development, community, shalom, GKII, Kupang

\section{Pendahuluan}

Gereja dalam pemahaman praktis berbicara mengenai organisme dan organisasi. Secara organisme, gereja adalah setiap pribadi yang dipanggil keluar dari kegelapan ke dalam terangnya yang ajaib (1 Petrus 2:9-10). Gereja memiliki persekutuan pribadi dengan Kristus sebagai Tuhan dan Juruselamatnya (Yohanes 1:12; Yohanes 17:3). Secara organisasi, gereja berbicara mengenai persekutuan pribadi-pribadi dalam suatu komunitas bersama yang di dalamnya perlu diatur secara tertib. Dalam hal inilah diperlukan pemimpin secara rohani dengan Kristus sebagai Kepalanya. Dalam perutusannya gereja diutus oleh Kristus ke dalam dunia, namun ia bukan berasal dari dunia. Dalam interaksinya dengan dunia di mana ia hidup dan menyaksikan akan kebesaran Allah. Pada sisi yang lain, orang percaya yang adalah gereja, diperhadapkan dengan berbagai masalah sosial, ekonomi, politik, pendidikan, kesehatan dan berbagai masalah sosial lainnya yang juga menjadi pergumulan masyarakat secara umum. Dalam kondisi inilah, pada satu sisi orang percaya dipanggil dalam pengharapan akan kemuliaan Allah di dalam Kristus suatu kehidupan Surga yang penuh dengan kedamaian. Pada sisi lain, ia ada di dunia yang penuh dengan penderitaan dan tantangan yang juga menerpa kehidupannya. Kenyataan tersebut di atas menjadi perenungan bagi gereja disebutkan:

Gereja Kristen masa kini sudah lama melalaikan peran aktifnya di bidang sosial. Selain tindakan karitas dalam kegiatan amal yang dilakukan sekalikali dan pe-layanan pendidikan dan kesehatan yang bahkan kehilangan visi kristianinya, umumnya gereja gagal memberikan pengaruhnya yang positif dalam kehidupan sosial di masyarakat. Orang-orang Kristen secara salah menganggap iman Kristen secara salah menganggap iman Kristen hanya berkenaan dengan kesalehan per-sonal dan tidak berkenaan dengan kehidupan publik, sehingga tidak merasa berkewajiban untuk memikirkan tanggungjawab sosialnya. Karena itu, Kuyper mengingatkan kita bahwa 
iman Kristen sejati harus terintegrasi dalam seluruh aspek kehidupan, termasuk bidang sosial politik. Bagi Kuyper, ketika seorang Kristen hidup berdasarkan prinsip ajaran Kitab Suci, ia tidak bisa tidak memerhatikan dan mengusahakan kehidupan sosial yang lebih baik bagi masyarakat di mana ia di-tempatkan.

Juga dijelaskan, "Dalam konteks modernisasi, gereja memang perlu membangun diri agar tidak ketinggalan anggota jemaatnya, namun juga tidak boleh lupa akan tugas dan panggilannya untuk membangun masyarakat. Mengingat hal ini, maka teologi praktis perlu memberikan sumbangan pemikiran untuk mengarahkan gereja dalam perencanaan pembangunan jemaat yang kontekstual."2 Gereja hidup dan berkembang bukan untuk dirinya sendiri tetapi untuk membangun Kerajaan Allah yang mendatang-kan damai sejahtera, keadilan, dan kebenaran di bumi ini. ${ }^{3}$ Gereja yang adalah lembaga yang dibangun oleh Kristus dan dilengkapi oleh Kristus dengan kuasa-Nya untuk menghadirkan Kerajaan Allah di bumi menjadi harapan dan sarana di mana Allah bekerja bagi dan melalui umat-Nya untuk memberkati masyarakat.

Kemiskinan Asia dan perjuangan untuk hidup merupakan seruan bagi gereja-gereja Asia dan teologi Kristen untuk kembali pada aspirasiaspirasi dasar dari Kekristenan dalam Kitab Suci, hidup Yesus, dan gereja mula-mula, yang sangat memedulikan hidup manusia dan keadilan. ${ }^{4}$ Gereja selalu bergumul dengan dunia di mana ia diutus. Gereja bergumul dengan teks dan konteksnya, sehingga gereja tetap menjalankan fungsinya menjadi garam dan terang bagi dunia. Yan Aritonang, mengenai teologi kontekstual menjelaskan:

Dalam rangka mengembangkan teologi yang kontekstual tersebut dijagalah keseim-bangan antara teks (dalam hal ini isi dan berita Alkitab) dan konteks. Di satu sisi diupayakan agar teologi itu tetap setia pada teks, dan di sisi lain diupayakan agar relevan degaan - bahkan memberi penghargaan kepada - konteks. Namun demi-kian, pengembangan teologi kontekstual ini bukanlah pekerjaan yang mudah; sebab di satu sisi studi atas teks (Alkitab) juga terus berkembang, dan sering meng-hasilkan penemuan-penemuan baru dan mengejutkan, sedang di sisi lain konteks kehidupan dan keberadaaan gereja termasuk di Indonesia, antara lian di bidang sosial, politik, ekonomi, budaya (termasuk budaya modern), terus berubah, bahkan

${ }^{1}$ Abraham Kuyper, Iman Kristen dan Problema Sosial (Surabaya: Momentum, 2004), $\mathrm{x}$-ix.

${ }^{2}$ Rijnardus A. Van Kooij, Sri Agus Patnaningsing, dan Yam'ah Tsalatsa A., Menguak Fakta, Menata Karya Nyata (Jakarta: BPK Gunung Mulia, 2007), 4.

${ }^{3}$ Rijnardus A. Van Kooij, Sri Agus Patnaningsing, dan Yam'ah Tsalatsa A., Menguak Fakta, Menata Karya Nyata, 6.

${ }^{4}$ Tissa Balasuriya, Teologi Siarah (Jakarta: BPK Gunung Mulia, 1994), 150. 
penuh gejolak. Oleh karena itu, tugas dan tantangan dalam berteologi tidak pernah selesai, bahkan makin intensif, terutama ketika terjadi gejolak dan perubahan pada akhir-akhir ini. ${ }^{5}$

Dalam konteks Gereja Kemah Injil Indonesia ${ }^{6}$ secara nasional pergumulan untuk menuju kemandirian gereja yang ditandai oleh kemampuan gereja untuk membiayai segala kebutuhan pelayanan menjadi pergumulan. Dari data yang diperoleh penulis, disebutkan berhubungan dengan program kerja BPP GKII 1996-2001, yakni: ${ }^{7}$

Program Kerja BPP GKII 1996-2001. Mengacu kepada Anggaran Dasar Gereja Kemah Injil Indonesia, maka Program Kerja BPP GKII Periode 1996-2001 dikembangkan berdasarkan pernyataan misi yang berikut ini: Gereja Kemah Injil Indonesia ada untuk bersekutu, menyembah, memberitakan Injil dan melayani, membangun serta mendewasakan jemaat ke arah kemandirian, dalam melaksanakan Amanat Agung TUHAN Yesus Kristus (Matius 28:19-20).

Fokus utama yang merupakan tujuan ultima yang akan dicapai oleh BPP GKII periode 1996-2001 ialah "mengembangkan Gereja Kemah Injil Indonesia yang mandiri dan misioner" yang ditandai oleh:

1. Adanya kesadaran dan pengenalan diri semua anggota GKII sebagai "tubuh Kristus" yang terutus ke dalam dunia.

2. Adanya kemampuan untuk "membuat keputusan sendiri" tanpa campur tangan pihak luar.

3. Adanya potensi dan daya untuk "memerintah diri sendiri" dengan membangun organisasi GKII yang berfungsi secara efektif, efesien dan sehati, mulai dari tingkat jemaat, Daerah, Wilayah sampai pada tingkat pusat.

4. Adanya daya dan kemampuan untuk mengelola sumber daya manusia dan materi/ekonomi untuk "mencukupkan kebutuhan GKII" dalam melaksanakan semua tugas pelayanannya tanpa bantuan pihak luar.

5. Adanya dedikasi serta komitmen semua anggota untuk terlibat dalam penginjilan dan Misi Dunia, guna memenangkan orang-orang berdosa bagi kemuliaan TUHAN Yesus dalam lingkungan hidup di mana setiap anggota GKII berada.

6. Adanya hakikat, mekanisme yang kontekstual dan cara hidup Kristen semua anggota GKII yang ditandai oleh "hidup untuk mengabdi" dalam konteks pelayanan di mana GKII berada.

Pernyataan ini menunjukkan bahwa kemandirian pelayanan berhubungan erat dengan adanya daya dan kemampuan untuk mengelola

\footnotetext{
${ }^{5}$ Jan S. Aritonang, Belajar Memahami Sejarah di Tengah Realitas (Bandung: Jurnal Info Media, 2007), 44.

${ }^{6}$ Selanjutnya disingkat GKII

${ }^{7}$ Program Kerja BPP GKII 1996-2001. Pengantar, 1.
} 
sumber daya manusia dan materi/ekonomi (alam) yang Tuhan berikan kepada setiap jemaat. Ini berhubungan erat dengan pembangunan di dalam jemaat.

Pernyataan visi dan misi ini juga dicanangkan dalam konsep yang sama dalam periode pelayanan tahun 2001-2006, yakni:

Visi, yaitu "GKII ada untuk memuliakan Allah dengan menjadi Gereja pembawa damai sejahtera guna membangun manusia seutuhnya, dengan Misi, yang seleng-kapnya berbunyi: "GKII menerima dari Allah tanggungjawab untuk membawa damai sejahtera melalui Pekabaran Injil; Pelayanan Menyeluruh; Pendukungan (Jejaringan) dan Pengutusan." Serta Fokus, yaitu "membawa sejahtera" atau "shalom".

Penegasan juga diberikan berhubungan tema konferensi nasional GKII tahun 2006 serta visi, misi dan fokus pelayanan GKII untuk periode kerja 2006-2011, oleh ketua umum GKII yakni: ${ }^{9}$

Menyambut Konferensi Nasional Gereja Kemah Injil Indonesia Tahun 2006, BPP GKII mencanangkan tema: "Transforming the World through the Power of the Risen Christ, "(Transformasi dunia melalui kuasa Kristus yang bangkit) dan sub tema: "GKII dengan roh yang menyala-nyala siap menjadi alat pembaharuan untuk membawa sejahtera dalam segala bidang hidup" berlandaskan Wahyu 21:5. ... Berdasarkan tema dimaksud, BPP berupaya meletakkan landasan bagi strategi kepemimpinan dan manajemen dalam Periode Kerja 2006-201l, yang dibangun di atas Adapun VISI, MISI, dan FOKUS untuk digumuli bersama dalam KONAS ini. Adapun VISI, MISI dan FOKUS dimaksud adalah:

- Visi: "GKII ada untuk memuliakan Allah dengan menjadi alat transformasi guna membawa kesejahteraan bagi manusis seutuhnya" yang dirumuskan dalam pernyataan

- Misi: "GKII menerima dari Allah tanggungjawab menjadi alat trasformasi dunia melalui 'Pekabaran Injil, Pelayanan Menyeluruh, Pembangunan Berjejaring dan Pengutusan' dalam membangun masyarakat sejahtera" yang terarah kepada

- Fokus: yaitu "Shalom" atau "Transformasi yang membawa kesejahteraan" dalam segala bidang hidup.

Penjelasan visi, misi dan fokus menunjukkan adanya pergumulan GKII untuk membangun umat menuju kemandirian yang ditandai oleh damai sejahtera atau "shalom". Hal menarik yang dapat dilihat dari kata

\footnotetext{
${ }^{8}$ Sambutan Ketua Umum Gereja Kemah Injil Indonesia pada Konferensi Nasional VI Gereja Kemah Injil Indonesia tahun 2006. Dokumen Konas VI GKII. Wisma Kinasih, 20-24 Maret 2006, 2.

${ }^{9}$ Kata Pengantar Ketua Umum pada Konferensi Nasioanal VI Gereja Kemah Injil Indonesia tahun 2006. Dokumen Konas VI GKII. Wisma Kinasih, 20-24 Maret 2006, 16.
} 
pengantar Ketua Umum Badan Pengurus Pusat berhubungan dengan visi, misi dan fokus mempunyai tujuan yang menjelaskan:

Tema KONAS, Visi, Misi, dan Fokus yang dicanangkan di atas bertujuan guna mendorong semua komponen pemimpin dan warga GKII untuk memadukan hati, karsa, semangat dan daya guna melangkah memasuki masa pengabdian baru ke depan. Faktor penting yang diharapkan terjadi ialah bahwa GKII kiranya melangkah secara simultan dan terkoordinasi untuk mewujudkan kinerja bersinergi dalam segala bidang kehidupan, sehingga sejahtera yang didambakan akan terjadi dalam seluruh lapisan kehidupan umat GKII. Dambaan lain yang tersirat ialah bahwa dengan Visi, Misi dan Fokus kepemimpinan yang sama, diharapkan bahwa GKII mampu untuk menjadi alat trasformasi dalam segala bidang kehidupan umum (sosial, kultural, politik, kesehatan, pertanian, kelautan, teknologi, komunikasi, dan sebagainya) yang diwujudkan melalui pengabdian bersama dengan sesama anak bangsa, sehingga kesejahteraan pun diharapkan terwujud secara merata bagi semua anggota masyarakat. ${ }^{10}$

Tujuan ini dapat tercapai melalui suatu pendekatan yang dilakukan adalah pendekatan melalui pengembangan masyarakat. Ini dijelaskan:

Mewujudlangsungkan semua kinerja baik ini, BPP telah mencanangkan suatu landasan strategis (Manajemen Perencanaan Strategis) sebagai dasar bagi kinerja bersasaran ke depan, yang perlu kita godok serta gumuli dalam KONAS ini. Fokus utama dari MPS GKII ini adalah meneguhkan kepempinan pada semua aras (melatih, mengutus untuk belajar pada aras tinggi), membangun warga GKII sebagai masyarakat sejahtera dengan pendekatan community development yang diharapkan dapat mengentaskan tantangan yang dihadapi warga GKII. ${ }^{11}$

Ada suatu optimisme apabila ini dilaksanakan dengan baik memberi dampak secara positif yakni terwujudnya peradaban shalom. Ditegaskan pula: "Pada gilirannya, apabila hal ini dapat kita teruskan secara konsisten, maka akan ada transformasi yang membawa sejahtera dalam kehidupan individu, masyarakat, sehingga akan terwujudlah peradaban shalom (shalom civilization) di mana TUHAN Yesus Kristus akan terus diagungkan." ${ }^{12}$ Apa yang menjadi harapan ini, pada kenyataannya belum terwujud secara maksimal dalam kehidupan jemaat GKII secara khusus di Nusa Tenggara Timur. Kenyataan menunjukkan bahwa dari 65 jemaat yang ada dalam daerah pelayanan GKII Kupang-NTT ada 57 jemaat mandiri dan 10 Pos Penginjilan, hanya ada 19,4\% yang berada di pusat

\footnotetext{
${ }^{10}$ Kata Pengantar Ketua Umum, 16.

${ }^{11}$ Kata Pengantar Ketua Umum, 17.

${ }^{12}$ Kata Pengantar Ketua Umum, 17.
} 
kota dan kabupaten 80,6 \%, lainnya ada di pedesaan dengan tingkat kehidupan, pendidikan, ekonomi dan kesehatan pada umumnya masih minim bila dibandingkan dengan daerah lain yang ada di Indonesia. Satu indikasi yang dapat dilihat yakni adanya defisit anggaran GKII Daerah Kupang, pada laporan bendahara I pada Rakerda I September 2012, yakni Rp. 14.641.511. ${ }^{13}$ Ini menunjukkan bahwa gereja-gereja belum mampu membiayai sendiri pelaksanaan pelayanan melalui potensi sumber daya alam, sumber daya manusia, sosial dan rohani yang dimilikinya. Untuk mengatasi kondisi ini dan keadaan umat secara umum pada keputusan berhubungan dengan anggaran-anggaran. Dua keputusan yang berhubungan erat dengan pengembangan jemaat yang dapat sebagai titik tolak dalam merencanakan dan melaksanakan suatu strategi teologi pembangunan melalui pendekatan pengembangan masyarakat untuk menghadirkan shalom bagi umat yakni, pada poin e dan h, yakni:

e) Jemaat-jemaat lokal yang mempunyai tenaga ahli akan diinventarisir agar mereka juga dapat memberdayakan umat untuk memaksimalkan potensi yang ada dan dapat memberikan pelatihan-pelatihan praktis kepada Perkauan untuk mencari dana guna menolong anggaran Daerah yang sedang defisit. h) Daerah membentuk tim pemberdayaan umat untuk memaksimalkan potensi umat yang dimiliki. Diusulkan ada di bawah kaum profesional. $^{14}$

Pada sisi lain, dalam jemaat-jemaat ini ada potensi-potensi lokal yang dipunyai sumber daya alam (hutan, tanah, air), sumber daya sosial yang berupa hasil kebuda-yaan (hasil-hasil kebudayaan lokal, berupa kerajinan tangan) serta sumber daya manusia yang dapat dimaksimalkan untuk dapat mengatasi kesulitan-kesulitan kehidupan yang dialami.

Apa yang digumuli oleh Gereja Kemah Injil baik Secara Nasional maupun Daerah Kupang-NTT untuk meningkatkan derajat kehidupan umat berhubungan erat dengan apa yang sedang dipikirkan oleh Negara sesuai dengan tujuan bangsa yang dicanangkan dalam perencanaan pembangunan jangka panjang Nasional untuk Indonesia dari tahun 2005-2025 ke depan pasal 3, yang dijelaskan sebagai berikut:

RPJP Nasional merupakan penjabaran dari tujuan dibentuknya Pemerintahan Negara Indonesia yang tercantum dalam Pembukaan Undang-Undang Dasar Negara Republik Indonesia Tahun 1945, yaitu untuk

${ }^{13}$ Badan Pelaksana Harian Daerah Gereja Kemah Injil Indonesia, "Hasil Keputusan Rakerda I Gereja Kemah Injil Indonesia Daerah Kupang-NTT" di Sabu Raijua tanggal 57 September 2012, 6.

${ }^{14}$ Badan Pelaksana Harian Daerah Gereja Kemah Injil Indonesia, "Hasil Keputusan Rakerda I Gereja Kemah Injil Indonesia Daerah Kupang-NTT” di Sabu Raijua tanggal 57 September 2012, 13. 
melindungi segenap bangsa dan seluruh tumpah darah Indonesia, memajukan kesejahteraan umum, mencerdaskan kehidupan bangsa, dan ikut melaksanakan ketertiban dunia yang berdasarkan kemerdekaan, perdamaian abadi, dan keadilan sosial dalam bentuk rumusan visi, misi dan arah Pembangunan Nasional. ${ }^{15}$

\section{Pengertian Teologi Pembangunan}

Teologi pembangunan dapat diartikan sebagai ajaran Kristen mengenai suatu proses perubahan secara sadar yang dilakukan oleh manusia, baik secara pribadi maupun komunitas sebagai ciptaan Allah dalam penatalayanan ciptaan Allah secara utuh bagi kelangsungan kehidupan dan kesejahteraan ciptaan dengan melihat kepada Allah sebagai sumber utama pembangunan.

\section{Rencana Strategis Pengembangan Ekonomi Umat Menuju Masyarakat Shalom}

\section{Kondisi Nyata Gereja Kemah Injil Daerah Kupang-NTT}

Secara geografis Gereja Kemah Injil Indonesia Daerah Kupang NTT adalah daerah kepulauan yakni terdiri dari tiga pulau besar yang di dalamnya berdiam umat GKII Daerah Kupang-NTT, yang meliputi pulau Rote, pulau Timor dan pulau Sabu. Dalam struktur pemerintahan Propinsi Nusa Tenggara Timur umat Gereja Kemah Injil Indonesia Daerah Kupang-NTT berada dalam wilayah propinsi NTT yang di dalamnya terdapat dalam 5 kabupaten dan 1 kota yakni, kabupaten Rote-Ndao, kabupaten Sabu Raijua, kabupaten Kupang, Kabupaten Timor Tengah Selatan (TTS), Kabupaten Belu dan Kota Kupang dengan masalah dan karakteristik daerah yang berbeda.

Gereja Kemah Injil Daerah Kupang dalam upaya untuk menghadirkan shalom bagi umat yang dilayani diperlukan kemitraan dengan berbagai pihak untuk saling mendukung mencari jalan keluar yang dihadapi oleh umat berdasarkan potensi yang dimiliki oleh umat.

\section{Konsep Pengembangan Masyarakat Shalom Dalam Perspektif Teologi Pembangunan}

Pada bagian ini konsep pengembangan masyarakat secara umum yang coba dije-laskan meliputi pengertian pengembangan masyarakat,

\footnotetext{
15 "Undang-Undang Republik Indonesia Nomor 17 tahun 2007 tentang Rencana Pembangunan Jangka Panjang Nasional Tahun 2005-2025," diakses 5 April 2015, http://pendanaan.bappenas.go.id/index.php?option=com_rubberdoc\&view=doc $\&$ id $=40$ \&\&format=raw.
} 
aspek-aspek pengembangan masyarakat, tujuan pengembangan masyarakat, metode-metode pengembangan masyarakat dan prinsipprinsip pengembangan masyarakat.

\section{Pengertian Pengembangan Masyarakat}

Development community diartikan, "promosi kehidupan lebih baik pada masyarakat setempat, dengan partisipasi aktif, inisiatif maupun kerja sama seluruh warga masyarakat (pembangunan komuniti; pembangunan masyarakat setempat). ${ }^{16}$ Zubaegi menjelaskan, "Secara substansial pengembangan masyarakat adalah sebuah proses restrukturisasi masyarakat dengan cara menawarkan pola-pola swadaya partisipatif dalam mengelola dan mengorganisasikan kehidupan sosial-ekonomi sehingga akan lebih memungkinkan memenuhi kebutuhannya sendiri dibandingkan waktu-waktu sebelumnya. ${ }^{17}$ Lebih lanjut ia menulis, "pengembangan Masyarakat adalah upaya mengembangkan sebuah kondisi masyarakat secara berkelanjutan dan aktif berdasarkan prinsip keadilan sosial dan saling menghargai." ${ }^{18}$ Pengembangan masyarakat adalah komitmen dalam memberdayakan masyarakat lapis bawah sehingga mereka memiliki berbagai pilihan nyata menyangkut masa depannya." "Pengembangan masyarakat dapat didefinisikan sebagai metode yang memungkinkan individu-individu dapat meningkatkan kualitas hidupnya serta memperbesar pengaruhnya terhadap prosesproses yang memengaruhi kehidupannya." 20

Pengembangan Masyarakat adalah proses bertumbuhnya kemampuan suatu masyarakat untuk menyelesaikan sendiri segala persoalan mereka dan untuk memegang kendali atas hidup mereka. Ini menghasilkan pertumbuhan pribadi secara utuh (jasmani, jiwani, rohani, dan sosial) dan perbaikan dalam berbagai bidang kehidupan mereka, baik secara pribadi maupun secara bersama-sama. ${ }^{21}$

Pengembangan masyarakat dalam pengertian yang sama dengan perkembangan atau pembangunan masyarakat, Soetomo memberikan 4 konsep dasar yakni: ${ }^{22}$

\footnotetext{
${ }^{16}$ Soerjono Soekanto, Kamus Sosiologi (Jakarta: RajaGrafindo Persada, 1993), 147.

${ }^{17}$ M. Zubaegi, Pengembangan Masyarakat Wacana \& Praktik (Jakarta: Kencana Prenada Media Group, 2013), vi.

${ }^{18}$ M. Zubaegi, Pengembangan Masyarakat Wacana \& Praktik, 4.

${ }^{19}$ Zubaegi, 4.

${ }^{20}$ Ibid., 5.

${ }^{21}$ Gary T. Hipp, Pengembangan Masyarakat dan Pemuridan Perpaduan antara Kaidah Kencana dan Amanat Agung (Bandung: Kalam Hidup, 2005),30.

${ }^{22}$ Soetomo, Pembangunan Masyarakat Merangkai Sebuah Kerangka (Yogyakarta: Pustaka Pelajar, 2009), 25.
} 
1. Perkembangan atau pembangunan masyarakat pada dasarnya merupakan proses perubahan.

2. Perkembangan atau pembangunan masyarakat adalan proses terciptanya hubungan yang harmonis antara kebutuhan masyarakat dengan potensi, sumber daya dan peluang.

3. Perkembangan atau pembangunan masyarakat merupakan proses peningkatan kapasitas masyarakat untuk merespons berbagai persoalan yang berkembang.

4. Perkembangan atau pembangunan masyarakat merupakan proses yang bersifat mutidimensi.

Pengembangan masyarakat adalah salah satu metode pekerjaan sosial yang tujuan uta-manya untuk memperbaiki kualitas hidup masyarakat melalui pendayagunaan sumber-sumber yang ada pada mereka serta menekankan pada prinsip partisipasi sosial. ${ }^{23}$ Dalam pemahaman konsep dijelaskan pula: ${ }^{24}$

Pengertian pengembangan masyarakat, dalam pemahaman konsep terdiri dari dua kata yakni pengembangan dan masyarakat. Pengembangan atau pembangunan merupakan usaha bersama dan terencanan untuk meningkatkan kualitas kehidupan manusia, yaitu ekonomi, pendidikan, kesehatan dan sosial budaya. Masyarakat dapat diartikan dalam dua konsep, yakni:

1. Masyarakat sebagai sebuah "tempat bersama", yakni sebuah wilayah geografi yang sama.

2. Masyarakat sebagai "kepentingan bersama", yakni kesamaan kepentingan berdasarkan kebudayaan dan identitas.

Dari pengertian-pengertian di atas dapat disimpulkan bahwa pengembangan masyarakat adalah suatu komitmen yang lahir dari kesadaran akan keterbatasan kehidupan untuk dapat menolong diri sendiri melalui proses pengembangan potensi yang ada di dalam masyarakat secara partisipatif dan berkelanjutan menuju kepada kesejahteraan hidup secara utuh dan mandiri.

\section{Aspek-aspek Pengembangan Masyarakat}

Aspek-aspek pengembangan masyarakat dalam pemahaman umum dapat dijelaskan:

Sejarah menunjukkan bahwa ketika orang berbicara tentang "pengembangan", mereka pada umumnya berpikir tentang pengembangan ekonomi. Mereka akan memu-satkan pembicaraan pada hal-hal seperti

\footnotetext{
${ }^{23}$ Edi Suharto, Membangun Masyarakat Memberdayakan Rakyat.Kajian Strategis Pembangunan Kesejahteraan Sosial \& Pekerjaan Sosial (Bandung: Refika Aditamam 2005), 37.

${ }^{24}$ Edi Suharto, Membangun Masyarakat Memberdayakan, 39.
} 
pendapatan per kapita, Hasil Kotor Nasional, dan pengalihan informasi teknik. Akan tetapi, "pengembangan masyarakat" memiliki wawasan yang lebih luas yang mencakup bidang-bidang sosial, politik, dan budaya dari proses pengembangan. Penekanan utamanya adalah pada pengem-bangan pribadi-pribadi dalam masyarakat. $^{25}$

Penjelasan ini menunjukkan bahwa pengembangan masyarakat adalah suatu kesatuan yang utuh dalam pelaksanaan pembangunan. Ini sejalan dengan apa yang menjadi kebutuhan manusia yang mempunyai dimensi yang utuh.

Kehidupan masyarakat memiliki banyak dimensi yang tidak dapat dipisahkan satu sama lain. Kesejahteraan masyarakat tidak melulu hanya pemenuhan kebutuhan ekonomi, tetapi juga berarti pemenutuhan kebutuhan social politik, budaya dan religi. Krisis lingkungan terjadi karena pengembangan ekonomi yang membesar-besarkan kecenderungan konsumtif manusia, sebaliknya krisis ekonomi dapat terjadi karena kemiskinan sumber daya alam atau konflik social politik. Karena itu, pengembangan masyarakat secara holistik memiliki enam dimensi yang satu sama lain sering kali sulit dipisahkan atau dibedakan. ${ }^{26}$

Dari penjelasan-penjelasan di atas dapat menunjukkan aspek-aspek dari pengembangan masyarakat. "Adapun aspek-aspek dari pengembangan masyarakat tersebut, yakni, "pengembangan sosial (social development), pengembangan ekonomi (economic development), pengembangan politik (political development), pengembangan budaya (cultural development), pengembangan lingkungan (enviromental development), pengembangan individu/spiritual (personal/spiritual development)." 27

\section{Aspek Pengembangan Sosial}

Dalam pengembangan aspek sosial, ini lebih banyak dititik beratkan pada pengembangan sosial dari masyarakat yang perlu dikembangkan sebagai sarana pendukung sosial dalam proses perubahan secara sosial. Adapun kegiatan-kegiatan yang meliputi aspek pengembangan sosial ini meliputi: ${ }^{28}$

${ }^{25}$ Gary T. Hipp, Pengembangan Masyarakat dan Pemuridan Perpaduan antara Kaidah Kencana dan Amanat Agung (Bandung: Kalam Hidup, 2005), 29-30.

${ }^{26}$ Partisipasi, Pemberdayaan dan Demokratisasi Komunitas, Reposisi Participatory Rural Appraisal (PRA) (Bandung: Studio Driya Media, 2003), 10.

${ }^{27}$ Partisipasi, Pemberdayaan dan Demokratisasi Komunitas, Reposisi Participatory Rural Appraisal (PRA) (Bandung: Studio Driya Media, 2003), 11-14.

${ }^{28}$ Partisipasi, Pemberdayaan dan Demokratisasi Komunitas, Reposisi Participatory Rural Appraisal (PRA), 11. 
Pengembangan sosial dalam praktiknya, meliputi beberapa kategori kegiatan sebagai berikut:

- Kegiatan pelayanan sosial (isu-isu yang muncul, misalnya kurangnya fasilitas rekreasi/olahraga, kurangnya rumah penampungan, rumuh kumuh, perlunya panti jompo, kenakalan remaja, dan sebagainya).

- Pusat kegiatan masyarakat (yaitu pengembangan sarana kegiatan dan organisasi untuk interaksi sosial, misalnya: pendidikan non-formal, latihan, forum politik lokal, penelitian, kelompok diskusi, rekreasi/olahraga, dan sebagainya. Terutama untuk kebutuhan anakanak dan generasi muda)

- Kegiatan perencanaan sosial (misalnya, pembentukan komite masyarakat yang terlibat dalam penentuan prioritas kegiatan/program sosial di lingkungan masyarakatnya).

- Kegiataan animasi sosial (kegiatan-kegiatan untuk meningkatkan interaksi anggota masyarakat sehingga mereka memiliki perasaan kolektivitas dan kesiapan untuk berpartisipasi membangun masyarakatnya).

Mengenai pelayanan sosial sebagai bagian dari pengembangan masyarakat, juga dijelaskan yakni: ${ }^{29}$

Pengembangan masyarakat meliputi berbagai pelayanan sosial yang berbasis masyarakat mulai dari pelayanan preventif untuk mencegah anak-anak terlantar atau diperlakukan salah (abused) sampai pelayanan kuratif dan pengembangan untuk keluarga yang berpendapatan rendah agar mereka mampu memenuhi kebutuhan dasarnya.

\section{Aspek Pengembangan Ekonomi}

Mengenai pengembangan ekonomi (economic development) dijelaskan: Pengembangan ekonomi dalam konsep pengembangan masyarakat, merupakan pandangan alternatif terhadap ekonomi global yang didominasi oleh industri besar (kapitalistik). Karena itu, gagasan utamanya adalah pengembangan ekonomi masyarakat yang bermanfaat bagi masyarakatnya sendiri (otonomi ekonomi).

Secara garis besar, pengembangan ekonomi dalam praktiknya, meliputi dua kategori kegiatan sebagai berikut: ${ }^{30}$

- Pengembangan ekonomi tradisional (yaitu pengembangan ekonomi lokal untuk berpartisipasi dalam pengembagan ekonomi yang lebih luas, misalya: menarik investor dari luar, mengembangkan industri lokal, pengembangan pariwisata).

${ }^{29}$ Edi Suharto, Membangun Masyarakat Memberdayakan Rakyat Kajian Strategis Pembangunan Kesejahteraan Sosial \& Pekerjaan Sosial (Bandung: Refika Aditamam 2005), 37.

${ }^{30}$ Partisipasi, Pemberdayaan dan Demokratisasi Komunitas.Reposisi Participatory Rural Appraisal (PRA) (Bandung: Studio Driya Media, 2003), 11. 
- Pengembangan ekonomi alternatif (yaitu pengembangan ekonomi yang berbasis pada otonomi ekonomi, misalnya: mengembangkan koperasi, bank masyarakat, usaha simpan pinjam dan alat tukar lokal).

Pemerintah dalam upaya pengembangan ekonomi kedua-duanya didorong untuk dapat terjadi, baik pengembangan ekonomi tradisional maupun ekonomi alternatif sejalan dengan pelaksanaan otonomi daerah bagi peningkatan pendapatan asli daerah untuk mendukung pelaksanaan pembangunan di daerah.

\section{Aspek Pengembangan Politik}

Pengembangan politik (political development) dalam aspek pengembangan masyarakat dapat dijelaskan sebagai berikut:

- Dalam banyak literatur, pengembangan politik seringkali disebut pengorganisasian masyarakat (community organizing), dalam paparan ini, pengembangan politik merupakan bagian dari konsep pengembangan masyarakat (community development).

- Pada pengembangan politik, isu pemberdayaan sangat mengemuka karena itu dalam program-program yang dilaksanakan, penting untuk melakukan analisis sosial (analisis kekuasaan), baik dalam level makro maupun mikro. Tujuan programnya adalah untuk mengembangkan kapasitas masyarakat secara keseluruhan di dalam arena politik yang lebih luas, serta mengembangkan kemampuan individu dan kelompokkelompok masyarakat untuk berperan serta dalam politik lokal.

- Pengembangan politik lokal dalam praktiknya, meliputi kegiatan sbb:

- Penyadaran masyarakat (terutama untuk penyadaran kritis tentang keterhubungan individu dengan struktur yang lebih luas).

- Pengorganisasian masyarakat (terutama untuk mengembangkan struktur politik lokal yang lebih otonomi yang menegakkan demokrasi dan kese-taraan antargolongan, etnis, gender).

Pengembangan politik yang lebih luas, meliputi kegiatan sebagai berikut: ${ }^{31}$

a. Pengorganisasian masyarakat (terutama untuk mengembangkan kemampuan dalam melakukan aksi sosial dalam arena politik yang lebih luas: regional, nasional, bahkan international).

b. Aksi sosial (yakni aksi-aksi untuk memengaruhi dan berhubungan dengan arena politik yang lebih luas, misalnya: menyampaikan aspirasi mengenai kebijakan nasional yang akan berpengaruh terhadap lokal.

Suatu contoh menarik yang dilaksanakan dewasa ini dalam hubungannya dengan aspek pengembangan politik dilaksanakan oleh Institut Leimena yakni, diskusi warga. Dijelaskan:

${ }^{31}$ Partisipasi, Pemberdayaan dan Demokratisasi Komunitas.Reposisi Participatory Rural Appraisal (PRA) (Bandung: Studio Driya Media, 2003), 12. 
Diskusi warga adalah sebuah bentuk diskusi dalam kelompok-kelompok kecil, di mana orang bertemu secara berkala untuk bersama-sama belajar hak dan tanggung jawabnya sebagai warga negara. Mereka juga belajar bagaimana menanggapi masalah yang dihadapi dalam masyarakat, bangsa dan negara ini, sebagai warga ne-gara yang bertanggung jawab. Diskusi warga adalah langkah sederhana untuk ikut mempersiapkan warga negara yang dapat memimpin perubahan-perubahan besar demi kesejahteraan bersama. $^{32}$

Ini menunjukkan upaya mempersiapkan masyarakat bagi suatu perubahan pemahaman akan hak dan tanggung jawab warga negara dalam pembangunan bangsa.

\section{Aspek Pengembangan Budaya}

Aspek pengembangan masyarakat dalam pengembangan budaya (cultural development) dapat dijelaskan sebagai berikut:

- Dalam era komunikasi dan informasi yang terbuka dan tanpa batas saat ini, sulit bagi suatu masyarakat untuk tetap mempertahankan kebudayaan lokalnya yang unik. Dalam globalisasi kebudayaan itu, seringkali terjadi pengolong-golongan budaya, misalnya: budaya yang lebih tinggi dan rendah, budaya maju dan terbelakang, budaya tradisional dan modern, dsb. Sehingga memunculkan inferioritas pada suatu kelompok budaya tertentu.

- Pengembangan kebudayaan adalah bagian yang penting dalam pengembangan masyarakat, yaitu untuk menumbuhkan sikap kritis terhadap identitas budaya, menghargai dan bangga pada identitasnya sendiri, menghargai keberagaman budaya dan dapat hidup berdampingan dalam perbedaan (keberagaman) tersebut.

Pengembangan budaya dalam praktiknya, meliputi kegiatan sebagai berikut: ${ }^{33}$

- Mempertahankan dan menghargai budaya lokal (lokal culture) dengan menghidupkan kembali elemen-elemen penting kebudayaan lokal agar timbul perasaan identitas kebudayaan dan kebanggaan terhadapnya. Tetapi harus dipertimbangkan agar tidak dimunculkan budaya elitis dan budaya yang tidak relevan dengan keseluruhan nilai (visi) masyarakat.

- Mempertahankan dan menghargai budaya asli (indigenous culture) dengan kegiatan yang sama seperti di atas, tetapi isu ini dianggap khusus

\footnotetext{
32 “Apa itu Diskusi Warga," diakses 2 April 2015,

http://www.leimena.org/id/page/v/ll4/apa-itu-diskusi-warga.

${ }^{33}$ Partisipasi, Pemberdayaan dan Demokratisasi Komunitas, Reposisi Participatory Rural Appraisal (PRA) (Bandung: Studio Driya Media, 2003), 12-13.
} 
karena masyarakat asli seringkali menjadi kelompok yang tersingkir oleh ekspansi budaya lain.

- Mengembangkan penghargaan terhadap keberagaman budaya (multiculturalism) dengan memperkenalkan prinsip-prinsip keadilan dan hak-hak asasi manusia sebagai nilai-nilai yang lebih universal dalam menjalankan kehidupan masyarakat yang multi-budaya.

- Mengembangkan budaya partisipatif (partisipatory culture) sebagai alternatif dari budaya tradisi (terutama bertujuan untuk mendorong masyarakat luas untuk berpartisipasi dan menghidupkan kegiatankegiatan kebudayaan daripada hanya sekedar sebagai penonton).

Kenyataan yang dapat dilihat dalam kehidupan masyarakat saat ini yakni digalakkannya berbagai sanggar-sanggar budaya lokal untuk mengembangkan kecintaan terhadap budaya-budaya asli masyarakat yang sarat nilai kemanusiaan.

Aspek Pengembangan Lingkungan

Aspek pengembangan masyarakat dalam bidang pengembangan lingkungan (environmental development) dapat dijelaskan sebagai berikut:

- Pengembangan lingkungan adalah upaya untuk memperbaiki lingkungan secara menyeluruh (bukan berdasarkan isu-isu spesifik, seperti: isu polusi, isu sampah/limbah, isu kesehatan lingkungan, dan sebagainya).

- Kegiatan-kegiatan pengembangan lingkungan antara lain: penyadaran, pendidikan, pengorganisasian masyarakat, perencanaan, dan sebagainya yang berkaitan dengan upaya mengembangkan pembangunan (sosial ekonomi) yang ramah lingkungan dan menggunakan prinsip berkelanjutan. ${ }^{34}$

Adanya upaya masyarakat untuk mengembangkan bank sampah, yakni mengelola sampah baik organik maupun anorganik untuk dapat dimanfaatkan kembali, baik berupa pupuk organik untuk tanaman holtikultura maupun sampah anorganik dari limbah plastik yang mempunyai nilai ekonomis untuk meningkatkan pendapatan keluarga.

Aspek Pengembangan Individu/Spiritual

Aspek pengembangan masyarakat di bidang pengembangan individu/spiritual (personal/spiritual development), dapat dijelaskan sebagai berikut: ${ }^{35}$

${ }^{34}$ Partisipasi, Pemberdayaan dan Demokratisasi Komunitas, Reposisi Participatory Rural Appraisal (PRA) (Bandung: Studio Driya Media, 2003), 13-14.

${ }^{35}$ Partisipasi Pemberdayaan dan Demokratisasi Komunikasi Reposisi Participatory Rural Appraisal (PRA), 14. 
- Pengembangan individu dalam konsep pengembangan masyarakat, lebih banyak dianggap sebagai bagian dari masalah karena menumbuhkan individualisme dan persaigan bebas, serta mempopulerkan idiom: "Saya bisa lakukan apa saja yang saya mau." Hal ini berarti tidak mengindahkan realitas struktur masyarakat, adanya keterbatasan lingkungan adanya perbedaan individu, serta mendorong sikap yang eksploitatif dan menyalahkan orang yang tidak mampu berkompetisi.

- Justru karena itu, pengembangan individu dalam pengembangan masyarakat menjadi penting, yaitu untuk memenuhi kebutuhan individu melalui jaringan dan interaksi dalam masyarakatnya, ketimbang melalui profesionalisme dan kesuksesan pribadi.

Marnia Nes dalam kaitan dengan pengembangan individu dalam hubungan dengan pengembangan masyarakat menulis:

Mahatma Gandhi, pejuang keadilan dari India, berpendapat bahwa dalam kehi-dupan manusia, pertumbuhan dan perkembangan aspek material dan non material harus berjalan seimbang dan harmonis. Hanya pertumbuhan yang mencakup aspek spiritual dan material inilah yang benar-benar bernilai bagi manusia. Kecenderungan atas kemajuan material yang tidak terbatas dapat menjadi rintangan bagi pencapaian kemajuan kemanusiaan. Pemenuhan kebutuhan material tanpa dibarengi dengan peningkatan kualitas akal budi akan menimbulkan keserakahan, persaingan yang tidak sehat, kesewenang-wenangan dari pihak-pihak yang dominan, ketidakadilan dan sebagainya. $^{36}$

Penjelasan-penjelasan ini menunjukkan aspek pengembangan individu/spiritual menjadi hal terpenting sebagai penyeimbang dalam setiap aspek pengembangan masyarakat karena bersentuhan langsung dengan pribadi yang melaksanakan pembangunan.

\section{Tujuan Pengembangan Masyarakat}

Tujuan pengembangan masyarakat berhubungan dengan perubahan kehidupan dari masyarakat ke arah yang lebih baik dalam standar kemanusiaan. Standar kemanusiaan dapat menjadi berbeda dari berbagai penilaian. Namun setidaknya masyarakat tersebut sejahtera, tercukupi segala kebutuhan dasarnya. Ia dapat mengelola kehidupan dengan memaksimalkan potensi yang ada padanya baik potensi sumber daya manusia, sumber daya sosial dan sumber daya alam dan rohani yang

\footnotetext{
${ }^{36}$ Marnia Nes "Pembangunan Manusia” dalam Kumpulan Bahan Bacaan Pelatihan Dasar PEMDA. Program Nasional Pemberdayaan Masyarakat (PNPM) Mandiri Perkotaan (Jakarta: Kementeriaan Pekerjaan Umum Direktorat Jenderal Cipta Karya, nd), 14.
} 
dimilikinya. Manusia mandiri menjadi tujuan pengembangan masyarakat.

Fokus pembangunan bukan lagi kepada ekonomi, sosial dan teknologi, melainkan pada manusia itu sendiri. Pembangunan menurut paradigma pemanusiaan adalah pembangunan manusia itu sendiri untuk menjadi manusia utuh dan merdeka atau secara ekonomi produktif dan secara sosial efektif. ${ }^{37}$ Manusia sebagai tujuan pengembangan dari masyarakat juga ditegaskan oleh A. Yewangoe, yakni:

Saya tertarik oleh wawancara Radio Nederland dengan Prof. Dr. Edi Swansono, 27 November 1993. Dia menegaskan pentingnya manusia sebagai sentral. "Bukan membangun ekonomi, kita bukan membangun gedung, jalan bahkan industri," kata Swasono "tetapi manusia" Dalam hubungan ini dia mengemukakan dua kata kunci, yaitu partisipatoris dan emansipatoris. Yang dimaksud dengan yang per-tama adalah kemampuan pembangunan itu sendiri menggerakkan rakyat untuk ikut di dalamnya. Mereka bukan hanya penonton. Atau yang paling tragis, bukan sebagai yang digeser dan digusur. Sedangkan kata kedua bermakna bahwa pembangunan mestinya mengangkat manusia ke taraf sederajat dengan orang-orang lainnya. Tidak boleh pembangunan menempatkan manusia pada divisi-divisi. Pembangunan tidak boleh bersifat sektarian, yang menempatkan manusia Indone-sia pada kelompok yang menikmati hasil-hasil pembangunan dan kelompok yang tidak mendapatkan apa-apa. Pada hemat saya, pembangunan manusia merupakan dasar yang teguh di atas pembangunanpembangunan lainnya asalkan pemba-ngunan manusi tidak diartikan secara dangkal. Pembangunan manusia meliputi komitmen, konsistensi, konsekuensi menjalankan pekerjaan, disiplin dan keteladanan. Semua unsur ini dilandasi oleh penghormatan yang tinggi terhadap harkat dan martabat manusia sebagai gambar Allah (4 Desember 1993). ${ }^{38}$

Tujuan pengembangan masyarakat tidak terlepas dari perspektif pengembangan masyarakat atau arah dari pengembangan masyarakat itu sendiri. Adapun perspektif pengembangan masyarakat secara umum terdapat dua perspektif ini dapat digambarkan ini dapat memberikan gambaran yang luas mengenai suatu pendekatan yang baik dalam melakukan suatu upaya bagi terlaksananya suatu proses pengembangan masyarakat dalam suatu wilayah. Adapun perspektif tersebut adalah: ${ }^{99}$

${ }^{37}$ Parwoto "Paradigma Pembangunan" dalam Kumpulan Bahan Bacaan Pelatihan Dasar PEMDA. Program Nasional Pemberdayaan Masyarakat (PNPM) Mandiri Perkotaan (Jakarta: Kementeriaan Pekerjaan Umum Direktorat Jenderal Cipta Karya, nd), 9-10.

${ }^{38}$ A. A. Yewangoe, Iman, Agama dan Masyarakat dalam Negara Pancasila (Jakarta: BPK. Gunung Mulia, 2011), 231.

${ }^{39}$ Edi Suharto, Membangun Masyarakat Memberdayakan Rakyat Kajian Strategis

Pembangunan Kesejahteraan Sosial \& Pekerjaan Sosial (Bandung: Refika Aditama, 2005), 41. 
Tabel 1. Pendekatan, Perspektif dan Tujuan Pengembangan Masyarakat

\begin{tabular}{|l|l|l|}
\hline \multicolumn{1}{|c|}{ Pendekatan } & \multicolumn{1}{|c|}{ Perspektif } & \multicolumn{1}{c|}{ Tujuan / Asumsi } \\
$\begin{array}{l}\text { Profesional } \\
\text { (Tradisional, } \\
\text { Netral, } \\
\text { Teknikal) }\end{array}$ & $\begin{array}{l}\text { Perawatan masyarakat } \\
\text { Pengorganisasian } \\
\text { masyarakat. } \\
\text { Pembangunan } \\
\text { masyarakat. }\end{array}$ & $\begin{array}{l}\text { Meningkatkan inisiatif dan } \\
\text { kemandirian masyarakat. } \\
\text { Memperbaiki pemberian pelayanan } \\
\text { sosial dalam kerangka relasi sosial yang } \\
\text { ada. }\end{array}$ \\
\hline $\begin{array}{l}\text { Radikal } \\
\text { (Trans- } \\
\text { formasional) }\end{array}$ & $\begin{array}{l}\text { Aksi masyarakat } \\
\text { berdasarkan kelas }\end{array}$ & $\begin{array}{l}\text { Meningkatkan kesadaran dan inisiatif } \\
\text { masyarakat. } \\
\text { Aksimasyarakat }\end{array}$ \\
& $\begin{array}{l}\text { Merdasarkan gender } \\
\text { Aksi masyarakat } \\
\text { berdasarkan ras }\end{array}$ & $\begin{array}{l}\text { mencari akar penyebab ketertindasan } \\
\text { dan diskriminasi. }\end{array}$ \\
& & $\begin{array}{l}\text { Mengembangkan strategi dan } \\
\text { membangun kerjasama dalam } \\
\text { melakukan perubahan sosial sebagai } \\
\text { bagian dari upaya mengubah relasi } \\
\text { sosial yang me-nindas, diskriminatif, } \\
\text { dan eksploitatif. }\end{array}$ \\
\hline
\end{tabular}

Dari penjelasan ini bahwa pada dasarnya tujuan dari kedua pendekatan ini adalah baik, bagi keseyahteraan masyarakat, hanya pendekatan atau cara yang perlu diperhatikan sehingga lebih manusiawi dan bagi seorang Kristen memuliakan Allah.

\section{Perencanaan Strategis Pengembangan Masyarakat Shalom GKII}

Pembangunan jemaat adalah proses yang berlangsung terus menerus atau berkesinambungan. Pengamatan, pengambilan komitmen untuk berubah, mempersiapkan dan melakukan penelitian, analisis masalah, refleksi teologis dan perencanaan strategis berlanjut kembali dalam evaluasi (pengamatan dan seterusnya). Seluruh proses dalam pembangunan jemaat kontekstual dapat digambarkan sebagai berikut:

Proses transformasi dalam pembangunan jemaat akan terjadi terusmenerus seperti yang digambarkan dalam model sistem terbuka. Jemaat terus-menerus melakukan proses berdialog secara kritis dengan diri sendiri dan dengan konteks masyarakat sambil terus menggumuli kehendak Allah. Proses pembangunan jemaat kontekstual tidak boleh berhenti dalam sebuah titik kepuasan. Kesediaan jemaat untuk terus berproses dalam gerak perubahan menjadikan kehidupan jemaat dinamis dan tidak stagnan, terus mencari kehendak Allah dalam perjalanan dan karya gereja serta memberi dampak dalam kehidupan masyarakat. ${ }^{40}$

Prinsip dasar pengelolaan kekayaan (aset daerah meliputi tiga hal utama: 1) Adanya perencanaan yang tepat; 2) Pelaksanaan/pemanfaatan

${ }^{40}$ Rijnardus A. Van Kooij, Sri Agus Patnaningsih, Yam'ah Tsalata A. Menguak Fakta, Menata karya Nyata (Jakarta: BPK. Gunung Mulia, 2007), 148-149. 
secara efisien dan efektif, dan 3. Pengawasan (monitoring). ${ }^{41}$ Ini yang coba dibuat sebagai acuan sederhana memberi arah bagi pengembangan ekonomi GKII ke depan untuk 2015-2020 sebagai perencanaan strategis tingkat menengah.

Dasar Hukum GKII Daerah Kupang telah menggumuli kondisi nyata umat yang perlu diberi pendampingan untuk mengembangkan potensi sumber daya alam yang Tuhan berikan adapun dasar hukum yang berhubungan erat dengan pengembangan ekonomi umat, keputusan Komisi B Bidang Program Kerja GKII Point 4. Pemberdayaan Jemaat yakni, "mengaktifkan dan meningkatkan koperasi daerah." Pada bagian $\mathrm{B}$, rekomendasi point c, BPD GKII terpilih bermitra dengan donasi dari dalam dan luar negeri demi kemajuan dan kesejahteraan GKII Daerah Kupang-NTT. ${ }^{42}$ Hasil Keputusan Rakerda I GKII Daerah Kupang-NTT di Sabu Raijua Tanggal 5-7 september 2012. Hasil Komisi C, kelembagaan menjelaskan:

Keputusan nomor ll yakni, BPD mendata kembali gereja-gereja secara terpadu. Dibuat tim sensus di setiap perwakilan dan diberikan SK oleh Daerah. sebelum tim turun, harus dilaksanakan pelatihan oleh BPD bekerjasama dengan dinas terkait. Diharapkan setiap gereja mempunyai data statistik yang akurat. BPD membuat format baku untuk keseragaman pendataan. Keputusan yang berhubungan dengan anggaran-anggaran. Point e disebutkan: Jemaat-jemaat lokal yang mempunyai tenaga ahli akan diinventarisir agar mereka juga dapat memperdayakan umat untuk memaksimalkan potensi yang ada dan dapat memberikan pelatihanpelatihan praktis kepada Perkauan untuk mencari dana guna menolong anggaran Daerah yang sedang defisit. Point h. Daerah membentuk tim perberdayaan umat untuk memaksimalkan potensi umat yang dimiliki. ${ }^{43}$

Juga ditegaskan dalam rapat kerja III GKII Daerah Kupang di Mizpa juga diputuskan: Hasil keputusan komisi B. Angka Romawi III bidang Keuangan point 2. Mendata potensi jemaat agar diakomodir oleh Daerah, STTIKK, dan Komisi Kaum Profesional, untuk meningkatkan sumber daya lokal dalam pemanfaatan lahan Daerah, Usaha Mikro kecil dan Menengah (UMKM), sehingga dapat menutupi defisit angaran. ${ }^{44}$

\footnotetext{
${ }^{41}$ Mardiasmo, Otonomi $\sim$ Manajemen Keuangan Daerah (Yogyakarta: ANDI, 2004), 238.

42 Badan Pelaksana Harian Daerah GKII, "Hasil Keputusan Konfrensi Daerah Gereja Kemah Injil Indonesia Daerah Kupang-NTT" (Kupang: STTIK 14-17 Juli 2011).

43 "Hasil Keputusan Rakerda I GKII Daerah Kupang-NTT" di Sabu Raijua Tanggal 5-7 September 2012.

44 "Hasil Keputusan Rapat Kerja III GKII Daerah Kupang -NTT" di GKII Mizpa TDM Kupang, 5-7 September 2013.
} 
Untuk mempersiapkan jemaat bagi peningkatan ekonomi berdasarkan potensi lokal yang dimiliki, juga dalam rapat kerja III di Mizpa telah diambil keputusan sebagai berikut:

Hasil Pleno Komisi C, bidang kelembagaan dan kemitraan nomor 4 point 3. Yakni BPHD mengupayakan terobosan dalam hal pelatihan-pelatihan untuk meningkatkan ekonomi jemaat. Point 4. BPHD menjalin kerjasama dengan pihak ketiga untuk meningkatkan kualitas hamba-hamba Tuhan secara holistik melalui pelatihan setiap tahun pada bulan Juli di kompleks STTIK Kupang, hal-hal teknis diatur kemudian. ${ }^{45}$

Berdasarkan keputusan-keputusan itulah perencanaan strategis ini disusun sebagai suatu masukan bagi peningkatan ekonomi pada GKII Daerah Kupang-NTT.

\section{Perencanaan Strategis Model Sederhana}

Analisis SWOT ${ }^{46}$

\begin{tabular}{|c|c|}
\hline $\begin{array}{l}\text { Strength/Kekuatan } \\
\text { 1. Gereja Kemah Injil Indonesia punya Badan } \\
\text { Hukum yang resmi pada Negera Republik } \\
\text { Indonesia. } \\
\text { 2. Mempunyai lembaga pendidikan } \\
\text { teologi. } \\
\text { 3. Kemitraan Pelayanan dengan } \\
\text { NPAC- Hongkong } \\
\text { 4. Adanya sumber daya manusia } \\
\text { yang berkompeten di bidang pendidikan, } \\
\text { kesehatan, ekonomi, pembangunan dan } \\
\text { lingkungan hidup dengan tingkat pendidikan } \\
\text { yang baik. } \\
\text { 5. Adanya kantor Gereja yang represtatif } \\
\text { 6. Potensi sumber daya alam, sosial } \\
\text { dan rohani yang dimiliki oleh umat. }\end{array}$ & $\begin{array}{l}\text { Weakness/Kelemahan } \\
\text { 1. Jumlah KK miskin cukup tinggi } \\
\text { 2. Penataan sistim keuagan gereja } \\
\text { yang belum seragam } \\
\text { 3. Pemanfaatan potensi sumber daya } \\
\text { alam, manusia, sosial, dan belum } \\
\text { Optimal. } \\
\text { 4. Program yang belum menyentuh } \\
\text { kebutuhan dasar jemaat. } \\
\text { 5. Jemaat belum mempunyai } \\
\text { keterampilan untuk memaksimalkan } \\
\text { potensi yang ada. } \\
\text { 6. Budaya konsumtif yang masih tinggi }\end{array}$ \\
\hline $\begin{array}{l}\text { Opportunities/Peluang } \\
\text { 1. Dana pemberdayaan yang disiapkan } \\
\text { pemerintah pusat kepada setiap desa } \\
\text { 2. Pembentukkan Kelompok Usaha bersama } \\
\text { dalam gereja } \\
\text { 3. Berjejaring dengan pemerintah. }\end{array}$ & $\begin{array}{l}\text { Threats/Ancaman } \\
\text { 1. Masyarakat ekonomi Asean } \\
\text { 2. Bahaya sekularisme akibat } \\
\text { perkembangan tekonologi dan informasi. } \\
\text { 3. Adanya masyarakat dari luar NTT yang } \\
\text { masuk dengan kemampuan ekonomi dan } \\
\text { ketrampilan } \\
\text { 4. Kurang pemahaman jemaat/pekerja } \\
\text { mengenai tanggungjawab gereja dalam } \\
\text { bidang ekonomi bagi pengembangan } \\
\text { masyarakat shalom. }\end{array}$ \\
\hline
\end{tabular}

45 "Hasil Keputusan Rapat Kerja III GKII Daerah Kupang -NTT" di GKII Mizpa TDM Kupang, 5-7 September 2013.

${ }^{46}$ Model perencanaan strategi ide diambil dari model perencanaan Strategis Pusat Pengembangan Anak IO 628-GKII Siloam Oebobo. 


\section{Pernyataan Visi dan Misi}

Pernyataan Visi (nama gereja) Gereja Kemah Injil Indonesia Daerah Kupang-NTT. Visinya: "Advokasi Transformasi membangun Masyarakat Damai." (Mendefiniskan 4 pertanyaan yang digabungkan. Mengapa kita ada? Siapa kita? Apa yang kita lakukan terus-menerus hari ini? Apa dampak dari pelayanan kita?). Sedangkan misinya: "GKII Daerah Kupang-NTT menerima dari Allah tanggungjawab menjadi alat trasformasi dunia melalui 'Pekaranan Injil, Pelayanan menyeluruh, pembangunan berjejaring dalam membangun masyara-kat sejahtera" yang terarah kepada fokus yaitu "Shalom" atau "Transformasi yang membawa kesejahteraan" dalam segala bidang kehidupan.

\section{Pernyataan Nilai-Nilai Utama (Core Values)}

(Nilai-nilai utama adalah ciri, sifat, kepercayaan atau karakter yang dianggap patut oleh orang-orang yang ada dalam organisasi itu yang memengaruhi prioritas, budaya dan cara pikir orang-orang).

\section{Tabel 2. Definisi Nilai-nilai Utama (Core Values)}

\begin{tabular}{|l|l|}
\hline Core Values & Pernyataan/definisi \\
\hline 1. Integritas & $\begin{array}{l}\text { Pelayanan yang berintegritas adalah seorang pribadi yang } \\
\text { bertanggung jawab terhadap sebuah pelayanan dan } \\
\text { mencapai keberhasilan }\end{array}$ \\
\hline 2. Tanggung Jawab & $\begin{array}{l}\text { Kesunguhan hati dalam melaksanakan pekerjaan yang } \\
\text { dipercayakan dan pantang menyerah dalam menghadapi } \\
\text { tantangan apapun }\end{array}$ \\
\hline 3. Loyalitas & $\begin{array}{l}\text { Rela mengorbankan waktu, tenaga, pikiran dan dana serta } \\
\text { mengasihi dan bertanggungjawab terhadap pekerjaan } \\
\text { yang ditekuni. }\end{array}$ \\
\hline 5. Kerjasama & $\begin{array}{l}\text { Sikap hati yang tulus ikhlas dan transparan dalam } \\
\text { melaksanakan pelayanan dengan takut akan Tuhan. }\end{array}$ \\
\hline 6. Penatalayanan & $\begin{array}{l}\text { Membangun kebersamaan dalam suatu pelayanan dengan } \\
\text { berbagai pihak sehingga dapat menjadi kekuatan yang } \\
\text { utuh untuk mencapai tujuan bersama. }\end{array}$ \\
\hline 7. Kesetiaan & $\begin{array}{l}\text { Pelayanan yang ditata denga baik akan mencapai hasil } \\
\text { yang maksimal. }\end{array}$ \\
\hline 8. Kemandirian & $\begin{array}{l}\text { Tidak pantang menyerah dan tuntas dalam melaksa-nakan } \\
\text { tugas yang dipercayakan. }\end{array}$ \\
\hline 9. Keberlanjutan & $\begin{array}{l}\text { Dapat melaksanakan tugas yang diberikan dengan } \\
\text { kemampuan sendiri dan kemampuan yang dimiliki dapat } \\
\text { menjadi berkat bagi orang lain serta berkelanjutan }\end{array}$ \\
\hline & $\begin{array}{l}\text { Melaksanakan program pembangunan yang memberi } \\
\text { dam-pak hasil yang berlanjutan baik bagi generasi } \\
\text { sekarang dan yang akan datang. }\end{array}$ \\
\hline
\end{tabular}

\section{Goals}

(Tema Strategis (misalnya 3-6) yang akan menolong organisasi mencapai tujuan akhirnya, yaitu mencapai visi yang ditentukan). 
Tabel 3. Tema Strategis dan Pernyataan Goal

\begin{tabular}{|l|l|}
\hline \multicolumn{1}{|c|}{ Tema Strategis } & \multicolumn{1}{c|}{ Pernyataan Goal } \\
\hline ekemandirian & $\begin{array}{l}\text { Gereja Kemah Injil Daerah Kupang mempunyai lembaga } \\
\text { keuangan mandiri yang dapat menolong gereja-gereja } \\
\text { menumbuhkan kemandirian ekonomi umat melalui unit- } \\
\text { unit usaha produktif sesuai potensi yang dimiliki oleh umat } \\
\text { dalam setiap gereja lokal. }\end{array}$ \\
\hline 2. Sumber daya alam & $\begin{array}{l}\text { Mengidentifikasi potensi sumber daya alam yang dimilikii } \\
\text { oleh setiap gereja lokal untuk dapat dikembangkan sebagai } \\
\text { sumber dana tetap menuju kemandirian ekonomi umat } \\
\text { dalam setiap gereja lokal. }\end{array}$ \\
\hline $\begin{array}{l}\text { 3. Sumber daya } \\
\text { manusia (SDM) }\end{array}$ & $\begin{array}{l}\text { Adanya peningkatan Sumber daya manusia secara } \\
\text { kempeten dengan potensi yang khas lebih untuk memenuhi } \\
\text { kepada kemandirian pelayanan }\end{array}$ \\
\hline 4. Sumber daya sosial & $\begin{array}{l}\text { Menumbuhkan kembangkan kearifan-kearifan lokal yang } \\
\text { dimiliki oleh umat sebagai kekuatan sosial dalam setiap } \\
\text { gereja lokal dalam mendukung program-program } \\
\text { pemberdayaan umat bagi kemandirian pelayanan }\end{array}$ \\
\hline $\begin{array}{l}\text { 5. Sumber daya } \\
\text { rohani }\end{array}$ & $\begin{array}{l}\text { Menumbuhkan pengajaran firman Allah yang kuat bagi } \\
\text { pengembangan iman umat dalam melaksanakan pelayanan } \\
\text { dalam gereja lokal dalam menghadapi tantangan zaman ini }\end{array}$ \\
\hline 6. Jejaring & $\begin{array}{l}\text { Membangun jejaring dengan lembaga milik negara, swasta } \\
\text { dan Lembaga suadaya masyarakat maupun gereja dalam } \\
\text { konteks lokal, regional, nasional maupun asing dalam } \\
\text { mengembangkan segala potensi yang dimiliki oleh gereja } \\
\text { dalam mendukung berbagai program yang menghadirkan } \\
\text { masyarakat shalom }\end{array}$ \\
\hline $\begin{array}{l}\text { Terpadu } \\
\text { mandiri }\end{array}$ & $\begin{array}{l}\text { Membangun kekuatan ekonomi umat dalam tingkat lokal } \\
\text { dan daerah melalui lembaga ekonomi mandiri baik secara } \\
\text { kecil yakni koperasi maupun lembaga keuangan mikro } \\
\text { lainnya untuk memberikan dukungan dana bagi setiap } \\
\text { kegiatan ekonomi produktif yang dilakukan oleh gereja. }\end{array}$ \\
\hline $\begin{array}{l}\text { Gereja Kemah Injil Daerah Kupang memiliki pusat pelatihan } \\
\text { kemandirian umat secara terpadu sebagai wadah yang } \\
\text { secara konsisten melatih dan mempersiapkan umat dengan } \\
\text { berbagai pengetahuan dan ketrampilan yang dapat } \\
\text { diaplikasikan secara nyata dalam memaksimalkan segala } \\
\text { potensi yang ada menuju kepada kemandirian dalam segala } \\
\text { bidang kehidiupan. }\end{array}$ \\
\hline
\end{tabular}

\section{Objektifdan Strategi}

Objektif harus SMART= specific (spesifik), measurable (terukur), achieveable (dapat dicapai), realistic (realistis), dan time-based (berdasarkan jangka waktu tertentu).

Goal 1: Kemandirian ekonomi: Gereja Kemah Injil Daerah Kupang mempunyai lembaga keuangan mandiri yang dapat menolong gerejagereja menumbuhkan kemandirian ekonomi umat melalui unit-unit 
usaha produktif sesuai potensi yang dimiliki oleh umat dalam setiap gereja lokal.

\section{Tabel 4. Objektif dan Strategi Kemandirian Ekonomi}

\begin{tabular}{|c|c|}
\hline Objektif (SMART) & Strategi (dengan cara apa/metode) \\
\hline \multirow{4}{*}{$\begin{array}{l}\text { 1.1. Lembaga Keuangan } \\
\text { mandiri }\end{array}$} & $\begin{array}{l}\text { 1.1.1. Melalui pembentukkan koperasi dalam } \\
\text { setiap gereja lokal } \\
\text { 1.1.2. Pembentukkan Tim sosialisasi manfaat } \\
\text { koperasi }\end{array}$ \\
\hline & $\begin{array}{l}\text { 1.1.3. Pembentukkan koperasi Induk pada } \\
\text { tingkat Daerah "Koperasi Kemah Sejahtera". }\end{array}$ \\
\hline & 1.1.4. Pengurusan badan Hukum Koperasi \\
\hline & 1.1.5. Pembangunan Sistem Kerja koperasi \\
\hline \multirow{3}{*}{$\begin{array}{l}\text { 1.2. Menumbuhkan } \\
\text { kemandirian ekonomi umat }\end{array}$} & $\begin{array}{l}\text { l.1.6. Seminar kewirausahaan bagi setiap } \\
\text { pendeta dan majelis pada setiap perwakilan dan } \\
\text { gereja lokal }\end{array}$ \\
\hline & $\begin{array}{l}\text { 1.2.l. Seminar mengenai pandangan Alkitab } \\
\text { mengenai pengembangan ekonomi umat menuju } \\
\text { kemandirian pelayanan gereja secara holistik. }\end{array}$ \\
\hline & $\begin{array}{l}\text { 1.2.2. Pelatihan teknologi hasil pertanian, } \\
\text { peternakan dan perikanan sesuai dengan potensi } \\
\text { dari setiap gereja lokal. }\end{array}$ \\
\hline 1.3. Unit-unit usaha produktif & $\begin{array}{l}\text { l. Terbentuknya unit-unit ekonomi produktif di } \\
\text { dalam setiap jemaat lokal sesuai dengan potensi } \\
\text { yang dimiliki umat. } \\
\text { 2. Adanya sistim manajemen yang dapat } \\
\text { mengontral dan mengawasi perkembangan } \\
\text { setiap unit-unit ekonomi produktif dalam setiap } \\
\text { gereja lokal dari tingkat perwakilan hingga } \\
\text { daerah. }\end{array}$ \\
\hline $\begin{array}{l}\text { 1.4. potensi yang dimiliki oleh } \\
\text { umat dalam setiap gereja } \\
\text { lokal. }\end{array}$ & $\begin{array}{l}\text { 1.4.l. Adanya data bass pada setiap gereja lokal, } \\
\text { perwakilan hingga daerah mengenai potensi yang } \\
\text { dimiliki oleh setiap gereja lokal yang dapat } \\
\text { diakses dengan mudah. Sebagai dasar pijakan } \\
\text { untuk melakukan perencanaan pengembangan } \\
\text { ekonomi umat dan informasi baik kepada } \\
\text { pemerintah maupun badan-badan sosial baik } \\
\text { dalam maupun luar negeri yang dapat membantu } \\
\text { pengembangan ekomi jemaat dalam setiap gereja } \\
\text { lokal dan daerah. }\end{array}$ \\
\hline
\end{tabular}

Goal 2: Sumber Daya Alam: Mengidentifikasi potensi sumber daya alam yang dimilikii oleh setiap gereja lokal untuk dapat dikembangkan sebagai sumber dana tetap menuju kemandirian ekonomi umat dalam setiap gereja lokal.

Tabel 5. Objektif dan Strategi Sumber Daya Alam

\begin{tabular}{|c|c|}
\hline Objektif (SMART) & Strategi (dengan cara apa/metode) \\
\hline 2.l. Mengidentifikasi & 2.l.1. Pembentukkan Tim identifikasi SDA \\
\hline
\end{tabular}




\begin{tabular}{|c|c|}
\hline \multirow{3}{*}{$\begin{array}{l}\text { potensi sumber daya } \\
\text { alam yang dimilikii } \\
\text { oleh setiap gereja } \\
\text { lokal }\end{array}$} & $\begin{array}{l}\text { 2.1.2. Perancangan dan pembuatan perangkat untuk } \\
\text { identifikasi potensi sumber daya alam gereja lokal }\end{array}$ \\
\hline & 2.1.3. Pelaksanaan identifikasi potensi SDM \\
\hline & $\begin{array}{l}\text { 2.1.3. Tersedianya data sumber daya alam dalam bentuk hard } \\
\text { copy dan soft copy yang dapat diakses dengan mudah bagi } \\
\text { perencanaan pengembangan SDA dalam setiap gereja lokal } \\
\text { dan pada tingkat Daerah }\end{array}$ \\
\hline \multirow{3}{*}{$\begin{array}{l}\text { 2.2.Pengembangan } \\
\text { Sumber Daya Alam } \\
\text { sebagai sumber dana } \\
\text { tetap bagi } \\
\text { pengembangan } \\
\text { ekonomi umat. }\end{array}$} & $\begin{array}{l}\text { 2.2.l. Adanya pelatihan-pelatihan ketrampilan bagi } \\
\text { pengembangan ekonomi jemaat secara tetap oleh Daerah } \\
\text { setiap } 3 \text { bulan sekali. }\end{array}$ \\
\hline & $\begin{array}{l}\text { 2.2.2. Adanya program untuk penaman pohon pada lahan- } \\
\text { lahan tidur milik jemaat dengan pohon-pohon umur } \\
\text { panjang yang bernilai ekonomi bermitra dengan pemerintah } \\
\text { dan swasta setiap tahun. }\end{array}$ \\
\hline & $\begin{array}{l}\text { 2.2.3. Terbentuknya kelompok-kelompok pencinta dan } \\
\text { penyelamat lingkungan dalam setiap gereja lokal nama } \\
\text { disesuaikan dengan kondisi dan budaya setempat. }\end{array}$ \\
\hline $\begin{array}{l}\text { 2.3.Kemandirian } \\
\text { ekonomi umat dalam } \\
\text { setiap gereja lokal. }\end{array}$ & $\begin{array}{l}\text { 2.3.l. Terbentuknya kelompok-kelompok usaha produktif } \\
\text { milik gereja yang dikordinir dengan baik oleh BPJ bidang } \\
\text { pengembangan ekonomi umat. }\end{array}$ \\
\hline
\end{tabular}

Goal 3: Adanya peningkatan Sumber Daya Manusia secara kompeten dengan potensi yang khas lebih untuk memenuhi kebutuhan pelayanan dalam gereja.

\section{Tabel 6. Objektif dan Strategi Sumber Daya Manusia}

\begin{tabular}{|c|c|}
\hline Objektif (SMART) & Strategi (dengan cara apa/metode) \\
\hline \multirow{3}{*}{$\begin{array}{l}\text { 3.l. Peningkatan sumber daya manusia } \\
\text { secara kompeten }\end{array}$} & $\begin{array}{l}\text { 3.1.l. Melalui pembentukan Pusat } \\
\text { Pelatihan dan pengembangan } \\
\text { kemandirian ekonomi umat di STTIK } \\
\text { Kupang setiap bulan Juli }\end{array}$ \\
\hline & $\begin{array}{l}\text { 3.1.2. Melakukan MOU dengan } \\
\text { Undana dan Poli Tani serta lembaga } \\
\text { pemerintah lainnya untuk pelatihan- } \\
\text { pelatihan bagi jemaat sesuai kekhasan } \\
\text { jemaat lokal. }\end{array}$ \\
\hline & $\begin{array}{l}\text { 3.1.3. Program magang pada pusat } \\
\text { pelatihan pertanian }\end{array}$ \\
\hline \multirow{2}{*}{$\begin{array}{l}\text { 3.2. Program Beasiswa Untuk Program } \\
\text { teknologi hasil pertanian, peternakan, } \\
\text { perikanan. }\end{array}$} & $\begin{array}{l}\text { 3.2.l. Mencari pemuda/pemudi yang } \\
\text { mempunyai pangilan untuk melayani } \\
\text { jemaat dalam bidang ekonomi. }\end{array}$ \\
\hline & $\begin{array}{l}\text { 3.2.2. Mencari sumber dana bagi } \\
\text { program beasiswa. }\end{array}$ \\
\hline
\end{tabular}

Goal 4: Menumbuhkan kembangkan kearifan-kearifan lokal yang dimiliki oleh umat sebagai kekuatan sosial dalam setiap gereja lokal dalam mendukung program-program pemberdayaan umat bagi kemandirian pelayanan 
Tabel 7. Objektif dan Strategi

\begin{tabular}{|l|l|}
\hline Objektif (SMART) & Strategi (dengan cara apa/metode) \\
\hline \multirow{4}{*}{$\begin{array}{l}\text { 1.1. Identifikasi Kearifan-Kearifan Lokal } \\
\text { yang dimiliki umat }\end{array}$} & $\begin{array}{l}\text { l.l.l. Membuat pendataan } \\
\text { Ketrampilan dan kemampuan seni } \\
\text { yang dimiliki oleh umat. }\end{array}$ \\
\cline { 2 - 2 } & $\begin{array}{l}\text { l.l.2. Program pelatihan Menenun bagi } \\
\text { genesi muda. }\end{array}$ \\
\hline \multirow{3}{*}{$\begin{array}{l}\text { 1.2. Program - program pemberdayaan } \\
\text { umat bagi kemandirian pelayanan }\end{array}$} & $\begin{array}{l}\text { l.2.l Program pengembanan kapasitas } \\
\text { kaum peremuan }\end{array}$ \\
& 1.2.l. Program usaha produktif \\
& keluarga \\
\hline
\end{tabular}

Goal 5: Menumbuhkan pengajaran firman Allah yang kuat bagi pengembangan iman umat dalam pelayanan gereja secara holistik dalam melaksanakan pelayanan dalam gereja lokal dalam menghadapi tantangan zaman ini.

\begin{tabular}{|l|l|}
\hline Objektif (SMART) & \multicolumn{1}{|c|}{ Strategi (dengan cara apa/ metode) } \\
\hline \multirow{4}{*}{ 2.l. Pengajaran Firman } & 2.l.1. Pelatihan pelayanan praktis dalam \\
& setiap gereja lokal. \\
\cline { 2 - 2 } & $\begin{array}{l}\text { 2.1.2. Pembuatan renungan harian } \\
\text { daerah "Batu Hidup" sebagai sarana }\end{array}$ \\
& pendewasaan umat dan peluang \\
& ekonomi pelayanan baru \\
\cline { 2 - 2 } & $\begin{array}{l}\text { 2.l.3. Penekankan pengajaran firman } \\
\text { berhubungan dengan kerja dan }\end{array}$ \\
& pembangunan ekonomi. \\
\hline
\end{tabular}

Goal 6: Membangun jejaring dengan lembaga milik negara, swasta dan Lembaga suadaya masyarakat maupun gereja dalam konteks lokal, regional, nasional maupun asing dalam mengembangkan segala potensi yang dimiliki oleh gereja dalam mendukung berbagai program yang menghadirkan masyarakat shalom.

Tabel 8. Objektif dan Strategi Membangun Jejaring

\begin{tabular}{|l|l|}
\hline \multicolumn{1}{|c|}{ Objektif (SMART) } & \multicolumn{1}{|c|}{ Strategi (dengan cara apa/metode) } \\
\hline 6.1. Membangun jaringan & \begin{tabular}{l} 
6.l. Pembuatan Website Resmi Daerah \\
\cline { 2 - 2 } \\
\cline { 2 - 2 }
\end{tabular} \\
$\begin{array}{l}\text { 6.2. Pembuatan profil Gereja Kemah Injil Daerah } \\
\text { Kupang-lengkap dengan potensinya. }\end{array}$ \\
\hline
\end{tabular}

Goal 7: Lembaga ekonomi mandiri: Membangun kekuatan ekonomi umat dalam tingkat lokal dan daerah melalui lembaga ekonomi mandiri baik secara kecil yakni koperasi maupun lembaga keuangan mikro lainnya 
untuk memberikan dukungan dana bagi setiap kegiatan ekonomi produktif yang dilakukan oleh gereja.

Tabel 9. Objektif dan Strategi Lembaga Ekonomi Mandiri

\begin{tabular}{|l|l|}
\hline \multicolumn{1}{|c|}{ Objektif (SMART) } & \multicolumn{1}{|c|}{ Strategi (dengan cara apa/metode) } \\
\hline \multirow{4}{*}{$\begin{array}{l}\text { 7.l. Membangun lembaga kekuatan } \\
\text { ekonomi umat. }\end{array}$} & $\begin{array}{l}\text { 2.l.1. Membangun Koperasi Daerah } \\
\text { 2.l.2. Mengalang kerja sama Dengan } \\
\text { berbagai lembaga untuk menguatkan } \\
\text { koperasi-koperasi milik gereja. }\end{array}$ \\
\cline { 2 - 2 } & $\begin{array}{l}\text { 2.l.3. Pelatihan keuangan mitro bagi } \\
\text { jemaat }\end{array}$ \\
\hline
\end{tabular}

Goal 8: Pusat Pelatihan Kemandirian Umat Terpadu: Gereja Kemah Injil Indonesia Daerah Kupang memiliki pusat pelatihan kemandirian umat secara terpadu sebagai wadah yang secara konsisten melatih dan mempersiapkan umat dengan berbagai pengetahuan dan keterampilan yang dapat diaplikasikan secara nyata dalam memaksimalkan segala potensi yang ada menuju kepada kemandirian dalam segala bidang kehidupan.

Tabel 10. Objektif dan Strategi Pusat Pelatihan Kemandirian Umat Terpadu

\begin{tabular}{|c|l|}
\hline Objektif (SMART) & \multicolumn{1}{|c|}{ Strategi (dengan cara apa/ metode) } \\
\hline 2.l. Pendirian Pusat Pelatihan & 2.1.l. Kantor GKII Daerah Kupang sebagai pusat \\
Kelatihan \\
\cline { 2 - 2 } Kemandirian Umat & $\begin{array}{l}\text { 2.1.2. STTIK Kupang sebagai pusat pelatihan } \\
\text { Kemandirian ekonomi jemaat }\end{array}$ \\
\hline
\end{tabular}

Perencanaan strategis ini akan dilanjutkan bersama dalam tim yang dibentuk oleh Badan Pengurus GKII Daerah Kupang sehingga menjadi panduan yang lengkap bagi pengembangan ekonomi GKII Daerah Kupang menuju masyarakat shalom.

\section{Kesimpulan}

Pertama, teologi pembangunan adalah ajaran Kristen mengenai suatu proses perubahan secara sadar yang dilakukan oleh manusia baik secara pribadi maupun komunitas sebagai ciptaan Allah dalam penatalayanan ciptaan Allah secara utuh bagi kelangsungan kehidupan ciptaan dengan melihat kepada Allah sebagai sumber utama pelaksana pembangunan.

Kedua, dasar teologi pembangunan dalam pelaksanaannya berhubungan erat dengan lima aspek yakni 1) perciptaan manusia sebagai gambar dan rupa Allah yang diberi kemampuan untuk bekerja 
memaksimalkan potensi yang dimiliki, baik potensi sumber daya manusia, sumber daya sosial, sumber daya alam dan sumber daya rohani untuk menghasilkan suatu perubahan sebagai hasil dari pelaksanaan pembangunan; 2) mandat pembangunan dalam Kejadian 1:26-28 dan Kejadian 2:15 yang memberikan pemahaman bahwa kuasa yang diberikan kepada manusia adalah kuasa untuk memelihara keberlanjutan kehidupan di bumi; 3) Pelanggaran manusia terhadap perintah Allah yang diberikan dalam Kejadian 2:16-17 telah memberi dampak kondisi manusia secara utuh mengalami dampak dari dosa; 4) Perjanjian Allah dalan sejarah manusia sejak dari Kejadian 3:15 hingga kedatangan Kristus yang pertama dan kedua kali yang berhubungan dengan perjanjian akan kemuliaan Allah, kehadiran kerajaan Allah di bumi menjadi dasar untuk melaksanakan pembangunan mengha-dirkan kerajaan Allah di tengah berbagai permasalahan yang dihadapi oleh umat manusia saat ini; 5) Karya Kristus menjadi teladan dalamm pelaksanaan teologi pembangunan sebagai pelaksanaan yang menyentuh seluruh aspek kehidupan manusia baik secara jasmani maupun rohani.

\section{Kepustakaan}

Abraham Kuyper, Iman Kristen dan Problema Sosial. Surabaya: Momentum, 2004.

“Apa itu Diskusi Warga.” Diakses 2 April 2015.

http://www.leimena.org/id/page/v/ll4/apa-itu-diskusi-warga.

Aritonang, Jan S. Belajar Memahami Sejarah di Tengah Realitas. Bandung: Jurnal Info Media, 2007.

Badan Pelaksana Harian Daerah Gereja Kemah Injil Indonesia. "Hasil

Keputusan Rakerda I Gereja Kemah Injil Indonesia Daerah Kupang-

NTT." Sabu Raijua, 5-7 September 2012.

Badan Pelaksana Harian Daerah GKII. "Hasil Keputusan Konfrensi

Daerah Gereja Kemah Injil Indonesia Daerah Kupang-NTT."

Kupang: STTIK 14-17 Juli 2011.

Balasuriya, T. Teologi Siarah. Jakarta: BPK. Gunung Mulia, 1994.

Dokumen Konas VI GKII. Wisma Kinasih, 20-24 Maret 2006.

Hasil Keputusan Rakerda I GKII Daerah Kupang-NTT. Sabu Raijua, 5-7

September 2012.

Hasil Keputusan Rapat Kerja III GKII Daerah Kupang -NTT. GKII Mizpa TDM Kupang, 5-7 September 2013.

Hipp, Gary T. Pengembangan Masyarakat dan Pemuridan Perpaduan antara

Kaidah Kencana dan Amanat Agung. Bandung: Kalam Hidup, 2005.

Ketua GKII. "Sambutan Ketua Umum Gereja Kemah Injil Indonesia."

Konferensi Nasional VI Gereja Kemah Injil Indonesia tahun 2006. 
Kooij, Rijnardus A. V., Sri Agus Patnaningsing, dan Yam'ah Tsalatsa A., Menguak Fakta, Menata Karya Nyata. Jakarta: BPK Gunung Mulia, 2007. Kumpulan Bahan Bacaan Pelatihan Dasar PEMDA. Program Nasional Pemberdayaan Masyarakat (PNPM) Mandiri Perkotaan. Jakarta:

Kementeriaan Pekerjaan Umum Direktorat Jenderal Cipta Karya, nd.

Mardiasmo. Otonomi e Manajemen Keuangan Daerah (Yogyakarta: ANDI, 2004.

Partisipasi, Pemberdayaan dan Demokratisasi Komunitas, Reposisi Participatory Rural Appraisal (PRA). Bandung: Studio Driya Media, 2003.

Soekanto, S. Kamus Sosiologi. Jakarta: RajaGrafindo Persada, 1993.

Soetomo. Pembangunan Masyarakat Merangkai Sebuah Kerangka (Yogyakarta: Pustaka Pelajar, 2009), 25.

Suharto, E. Membangun Masyarakat Memberdayakan Rakyat.Kajian Strategis Pembangunan Kesejahteraan Sosial e Pekerjaan Sosial. Bandung: Refika Aditamam 2005.

Zubaegi, M. Pengembangan Masyarakat Wacana \& Praktik. Jakarta: Kencana Prenada Media Group, 2013.

"Undang-Undang Republik Indonesia Nomor 17 tahun 2007 tentang Rencana Pembangunan Jangka Panjang Nasional Tahun 2005-2025." Diakses 5 April 2015.

http://pendanaan.bappenas.go.id/index.php?option=com_rubberdoc $\&$ view=doc\&id=40\&\&format=raw.

Yewangoe, A. A. Iman, Agama dan Masyarakat dalam Negara Pancasila Jakarta: BPK. Gunung Mulia, 2011. 